Historic, Archive Document

Do not assume content reflects current scientific knowledge, policies, or practices. 



\section{Prices Slashed for August and September Acceptance}

We Find that we have a surplus in the following items and in order to move this stock we are making a great reduction. Orders will be booked for Spring 1929] delbery, when onefourth cash accompanies order, and held in ftorage ingers new modern storage plant.

CHINESE ELM (Ulmus Pumila) Good thrifty stockypHoxents graded and packed to reach you in number one condition.

4-6 in. Seedlings

9-12 in. Seedlings

$12-18$ in. Seedlings

$18-24$ in. Seedlings

$2-3 \mathrm{ft}$. Seedlings

$\begin{array}{rrr}\$ 1.50 & \$ 10.00 & \$ 90.00 \\ 2.00 & 15.00 & 140.00 \\ 3.00 & 25.00 & 240.00 \\ 4.00 & 35.00 & 325.00 \\ 5.00 & 40.00 & 375.00\end{array}$

\section{EVERGREEN UNDER STOCKS}

BIOTA ORIENTALIS (Chinese Arbor Vitae) Once transplanted, right size for grafting.

$8-10$ in.

$10-12$ in.

$\$ 20.00 \quad \$ 175.00$

12-15 in

$25.00 \quad 200.00$

JUNIPER VIRGINIANA (Red Cedar) Two year seedlings,

right size for grafting.

6-8 in

8-10 in.

4-6 in. For lining out

6-8 in. For lining out

$\$ 45.00 \quad \$ 400.00$

$50.00-450.00$

$\$ 25.00 \quad \$ 200.00$

$35.00 \quad 300.00$

SCOTCH PINE. Once transplanted.

5-6 in.

6-8 in

$\$ 4.00 \$ 30.00$

$4.50 \quad 40.00$

AUSTRIAN PINE. Once transplanted.

5-6 in.

$\$ 4.00 \$ 30.00$

6-8 in.

$4.50 \quad 40.00$

PONDEROSA PINE. Once transplanted.

5-6 in.

6-8 in.

$\$ 4.00$

4.50

$\$ 30.00$

40.00

JACK PINE. Once transplanted.

6-8 in.

8-10 in.

$\$ 3.50 \$ \$ 30.00$

$4.00 \quad 35.00$

18-24 in.

$10.00 \quad 90.00$

BIOTA ORIENTALIS COMPAC'I'A

24-30 in.

Each

B\&B

$\$ 1.25$

$\begin{array}{lll}1.50 & 14.00 & 135.00\end{array}$

$B \& B$

$2.00 \quad 19.00 \quad 185.00$

JUNIPER VIRGINIANA (Platt River Cedar) Sheared Specimens. 3 times transplanted.

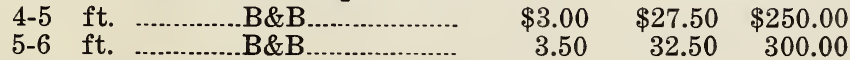

PINUS MUGHUS (Mugho Pine).

$12-18$ in. $B \& B$

$1.65 \$ 16.00 \$ 150.00$

\section{JACK PINE}

3-4 ft. Twice trans.

$\$ 1.50 \quad \$ 14.00 \quad \$ 125.00$

4-5 ft. Twice trans.

$2.00 \quad 19.00 \quad 175.00$

We have hundreds of other items in number one stock on which we would be glad to quote you special prices. If you can use a car load, loaded in bulk car, or on any items selected from our regular July list, we will allow you $10 \%$ discount.

\section{Kansas Evergreen Nurseries} Manhattan, Kansas 


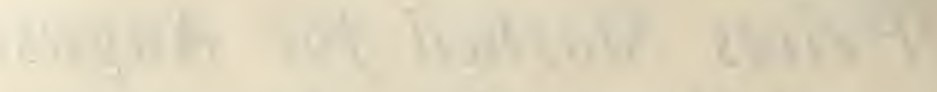

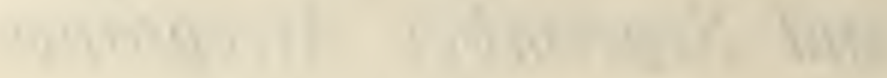

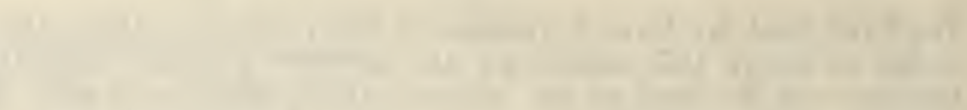

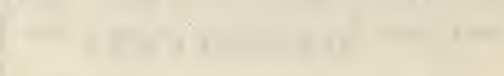

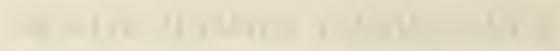
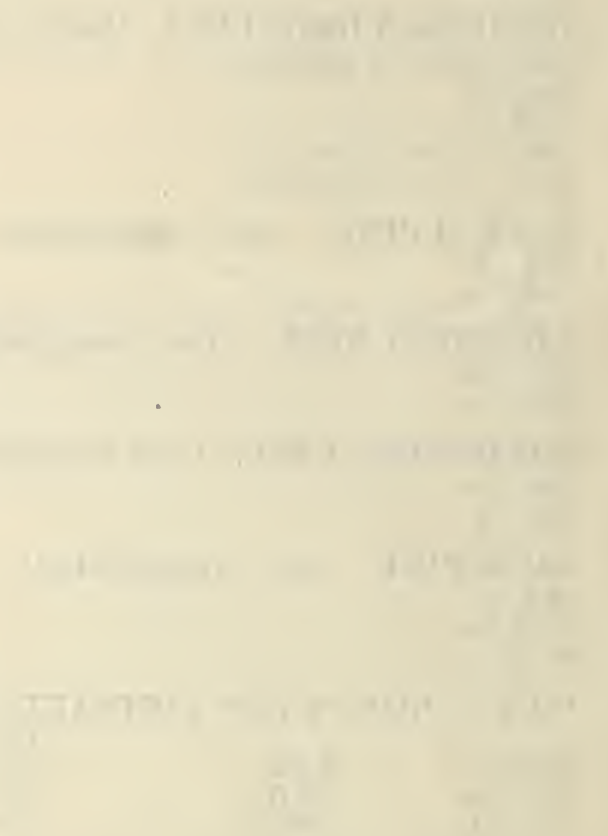
-

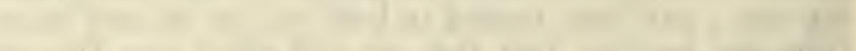

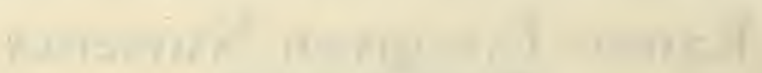

